\title{
Giant Cell Tumor of Bone
}

National Cancer Institute

\section{Source}

National Cancer Institute. Giant Cell Tumor of Bone. NCI Thesaurus. Code C121932.

A benign but locally aggressive tumor that arises from the bone and is composed of mononuclear cells admixed with macrophages and osteoclast-like giant cells. It usually arises from the ends of long bones or the vertebrae. Clinical presentation includes pain, edema, and decreased range of motion in the affected joint. 